Journal of Mechanical Engineering and Sciences

ISSN (Print): 2289-4659; e-ISSN: 2231-8380

Volume 12, Issue 4, pp. 4141-4160, December 2018

(C) Universiti Malaysia Pahang, Malaysia

DOI: https://doi.org/10.15282/jmes.12.4.2018.12.0358

\title{
The potential effectiveness of lean construction principles in reducing construction process waste: an input-output model
}

\author{
M.S. Bajjou* and A. Chafi \\ Faculty of Sciences and Techniques \\ University of Sidi Mohammed Ben Abdellah \\ B.P. 2202 - Route d'Imouzzer, Fez, Morocco \\ Department of industrial engineering \\ Industrial Techniques Laboratory \\ Phone: +212602675723 \\ * E-mail: mohamedsaad.bajjou@usmba.ac.ma
}

\begin{abstract}
With the spread of a culture of waste reduction in the construction industry, the traditional management system has become insufficient, so it has become crucial to implement more innovative techniques to improve the performance of this sector. In response to this need, Lean Construction (LC), which is the global reference of a production system with the minimum of waste generation, has attracted several construction companies all over the world. However, previous studies indicate that are several implementation scenarios that differ from one company to another according to their own understanding of the Lean Construction concept. In this paper, the authors attempt to fill this gap by proposing an original input-output model that aims at clarifying the main conceptual basis of Lean Construction philosophy, as well as establishing interactions between the main principles of this concept and all sources of wastes that exist in the construction industry. The proposed model shows nine main principles: customer focus, supply, continuous improvement, waste elimination, people involvement, planning and scheduling, quality, standardization and transparency. In addition, the practical relationships between those principles and nine sources of waste (transportation, motion, inventory, waiting, overproduction, defects, over-processing, unused employee creativity, and work Accidents) have been analysed.
\end{abstract}

Keywords: Lean Construction principles; sources of waste; waste reduction; practical relationships; input-output model.

\section{INTRODUCTION}

The sector of construction, according to several studies, is highly characterized by many problems such as low productivity, non-added-value generation, time and cost overrun, poor safety conditions, and a high variability of its construction process [1,2]. Indeed, several solutions had been proposed to overcome the weaknesses of the construction industry like the use of new computer technologies as Building Information modelling (BIM), the introduction of industrialization techniques through prefabrication, as well as automated and robotic construction processes. 
Despite the incorporation of new advanced materials and techniques that aim at improving the construction performance, this sector has not been able to gain a tremendous improvement in its production system compared to other industries such as the manufacturing industry and especially the automotive industry. This is mainly due to the absence of a strategy of the renovation of the traditional management techniques [3,4]. A lot of researchers [5-8] reported that these solutions alone cannot create a significant revolution for the construction industry, especially in the absence of a solid basis of management.

Lauri Koskela is the first researcher that though in introducing the lean philosophy into the construction industry. The application of lean to construction leads to several benefits such as the optimal use of the available resources, the elimination of wastes that do not add value to the customer, people involvement, and safety improvement [9]. This concept uses only half of resources (production space, workforce resources) in order to ensure respect of the triptych (quality, cost, time) and to achieve the customers' satisfaction. However, a closer analysis of literature shows that there is a lack of a clear vision of the main practices/techniques/ tools that constitute LC concept. Consequently, most of the construction companies have applied the lean management philosophy according to their own understanding of LC principles.

The objective of this paper is to design an input-output LC model in order to provide research community better explanations of the key elements of a successful implementation of the LC approach and to show the practical contributions of LC principles in reducing all sources of wastes that exist in the construction industry.

First, current models/frameworks of LC will be analysed and synthesized. The most relevant LC principles will be identified based on a review of five reliable models that have been validated and implemented in different countries (USA, UK, Germany, Brazil, and Malaysia). Then, the practical relationship between LC principles and nine types of wastes (transportation, motion, inventory, waiting, overproduction, defects, overprocessing, unused employee creativity, and work Accidents) will be investigated based on an in-depth review of related studies published in the most reliable databases.

\section{LEAN CONSTRUCTION MODELS}

\section{Rapid Lean Construction-Quality Rating Model (LCR)}

This model was developed in collaboration between two universities, the Brazilian University "Universidade Federal Paraná in Curitiba" and the German University Karlsruhe. It is based on six main principles (Client Focus, Waste Consciousness, Quality, Material flow \& pull, Organization/ planning /info flow, Continuous improvement, Kaizen).

The LCR model takes into consideration the evaluation of the six main principles together and shows a classification scheme which helps companies identify the level of maturity of construction projects. The degree of LC-implementation made a distinction between D-projects (lowest possible level-low quality and low improvement focus, wasteful) and AAA-projects (the highest level-strive for perfection in quality improvements and LC application), as shown in Table 1. 
Table 1. LCR level and results' interpretations [10]

\begin{tabular}{c|cc}
\hline Result & $\%$ achieved & Interpretation of level \\
\hline AAAA & $95 \%$ to $100 \%$ & (strive for perfection in quality improvements and LC \\
AA & $89 \%$ to $94 \%$ & application) \\
A & $81 \%$ to $88 \%$ & \\
BBB & $73 \%$ to $80 \%$ & \\
BB & $64 \%$ to $72 \%$ & (high-quality focus and lean-learning within the main \\
project/company levels)
\end{tabular}

\section{Lean Construction Maturity Model (LCMM)}

The LCM model contains eleven main key attributes (Culture \& Behaviour, Customer focus, Processes \& Tools, Business Results, Learning and Competency Development, Change, Work Environment, Way of Thinking, Improvement Enablers, Competencies). These key attributes can be divided into six main principles: Learning, People, Philosophy, Processes \& System, Leadership, and Outcomes \& Outputs, as shown in Figure 1. This model was validated through several interviews with LC experts that work as contractors, consultants, or engineers.

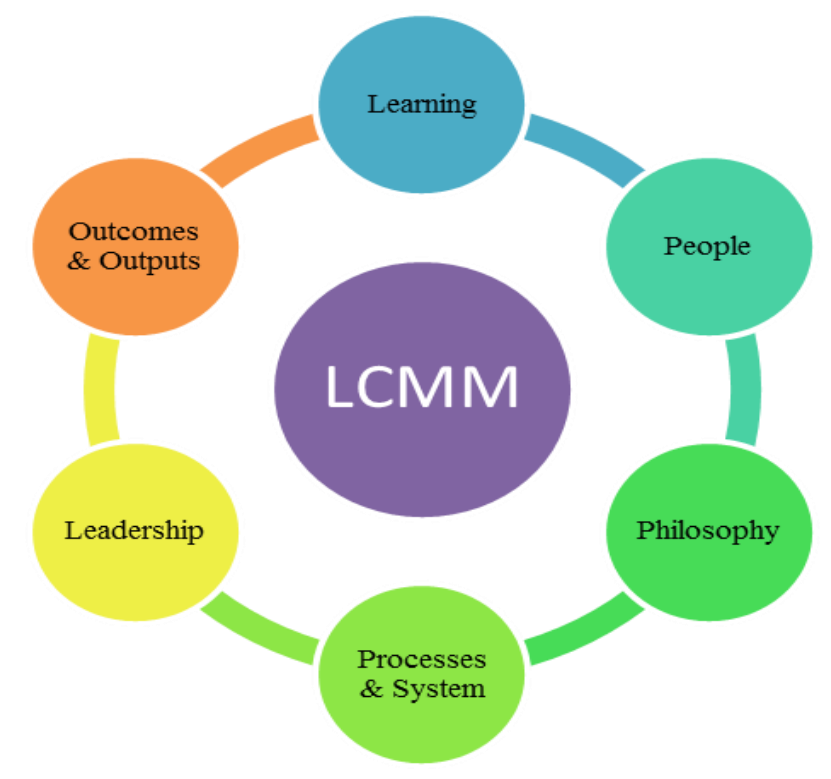

Figure 1. Lean Construction Maturity Model (LCMM) [11] 


\section{Lean Construction Framework (LCF)}

Qualitative and quantitative surveys were conducted in the German construction sector to investigate the consistency between the techniques implemented and LC concepts. The survey concerns sixty-one companies that are classified among the Top 100 construction companies in Germany. A conceptual framework was developed as shown in Figure 2.

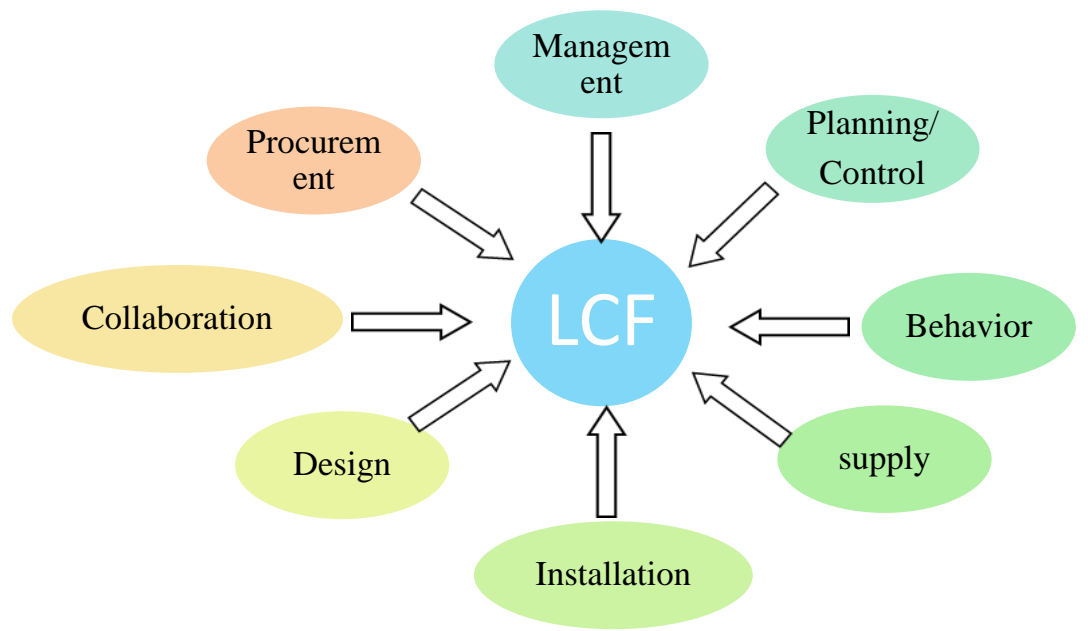

Figure 2. Conceptual Framework of Lean Construction in German construction industry [12]

\section{Lean Conformance Model (LCM)}

The Construction Industry Institute (CII), American organization specialized in improving the construction performance, carried out a study to identify the best practices of Lean Construction. As part of this work, the CII has developed a Lean Conformance Model, which is called Lean Construction Wheel. This model shows five main principles containing sixteen sub-principles, as illustrated in Figure 3.

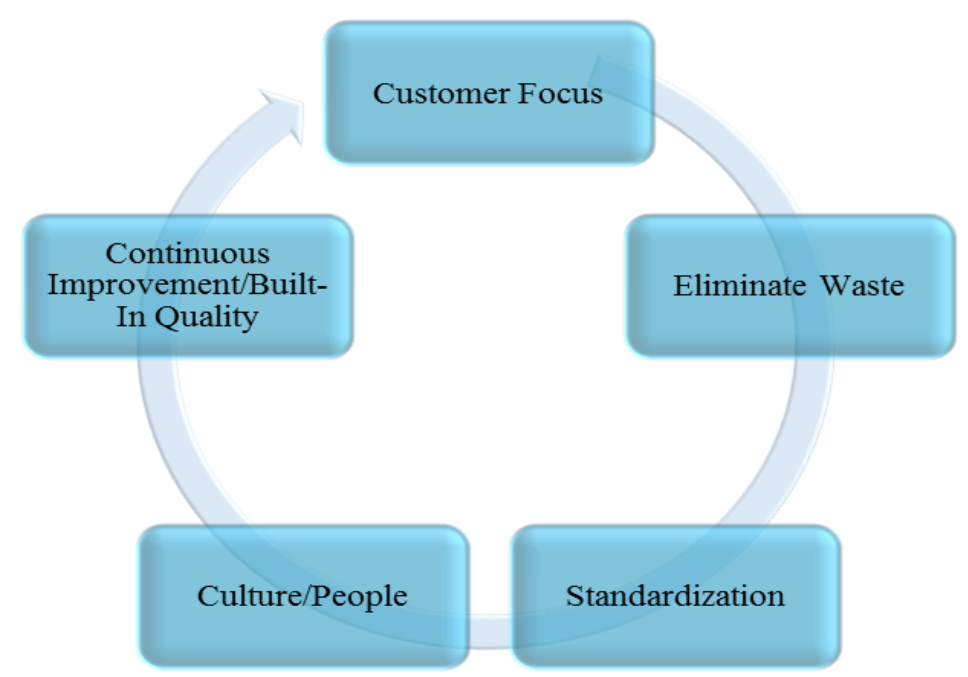

Figure 3. Lean Conformance Model [13] 


\section{Lean Construction Concept Model (LCCM)}

LCCM Model outlines the most relevant concepts of Lean Construction. This model is the output of a survey carried out in the Malaysian construction industry. This study aimed at summarizing the lean construction principles in an understandable model, to assess the consciousness of the lean construction principal among Malaysian construction companies. LCC Model summarizes seven Lean constructions principles and concepts (Specify value, Identify and map the value stream, Flow, Pull, Perfection/continuous improvement, Transparency, Process variability), as shown in Figure 4.

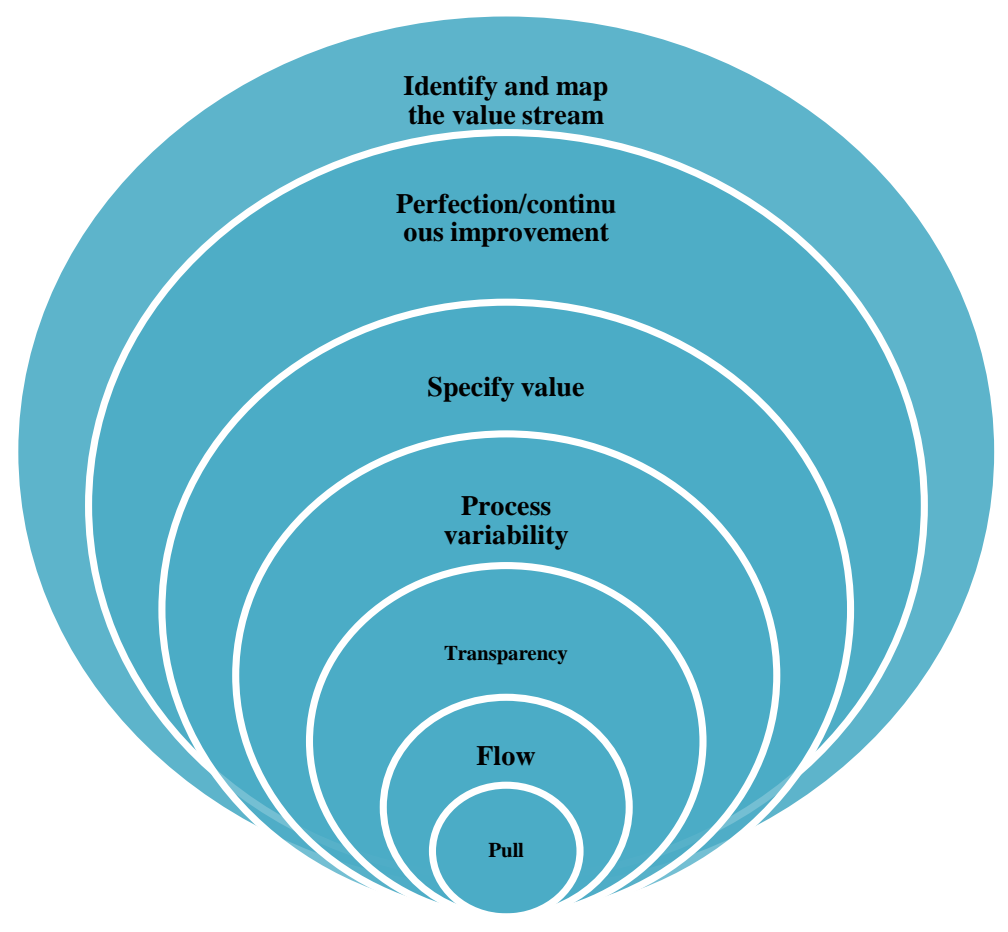

Figure 4. Lean Construction Concept Model (LCCM) [14]

\section{LEAN CONSTRUCTION PRINCIPLES}

In order to identify the main principles of Lean Construction, we have established a critical analysis of five Lean Construction models. These models are developed in different countries which are known for their performance and maturity at the level of understanding of LC concepts (United Kingdoms, United State, Germany, Brazil...). A full scope of all models that exist in the state of art would be impractical. So, only the most widespread and the most reliable models were reviewed as illustrated in Table 2. 
Table 2. Review of LC models

\begin{tabular}{|c|c|c|c|c|}
\hline No.Authors & Model name & Objectives & $\begin{array}{c}\text { Research } \\
\text { methodology }\end{array}$ & Countries \\
\hline$[10]$ & $\begin{array}{l}\text { Rapid Lean } \\
\text { Construction- } \\
\text { Quality Rating } \\
\text { Model (LCR) }\end{array}$ & $\begin{array}{l}\text { Evaluate the degree of } \\
\text { leanness and the quality of } \\
\text { a construction project } \\
\text { through a quantitative and } \\
\text { qualitative evaluation. }\end{array}$ & $\begin{array}{c}\text { Mindmap \& Brain- } \\
\text { storming }+ \\
\text { Evaluation of } 4 \\
\text { existing models }\end{array}$ & $\begin{array}{l}\text { Germany } \\
\text { and Brazil }\end{array}$ \\
\hline [11] & $\begin{array}{c}\text { Lean } \\
\text { Construction } \\
\text { Maturity Model } \\
\text { (LCMM) }\end{array}$ & $\begin{array}{l}\text { Measure the level of } \\
\text { maturity of construction } \\
\text { companies and make a } \\
\text { differentiating between } \\
\text { organizations "mature" and } \\
\text { "immature" in LC } \\
\text { implantation. }\end{array}$ & Interviews & UK \\
\hline [12] & $\begin{array}{l}\text { Lean } \\
\text { Construction } \\
\text { Framework } \\
(\mathrm{LCF})\end{array}$ & $\begin{array}{l}\text { Qualitative and quantitative } \\
\text { surveys were conducted to } \\
\text { investigate the current } \\
\text { understanding of Lean } \\
\text { construction principles } \\
\text { among German contractors. }\end{array}$ & Questionnaires & Germany \\
\hline [13] & $\begin{array}{c}\text { Lean } \\
\text { Conformance } \\
\text { Model (LCM) }\end{array}$ & $\begin{array}{l}\text { Identify the best practices } \\
\text { and the most commonly } \\
\text { used principles of Lean } \\
\text { Construction among the } \\
\text { members of The } \\
\text { Construction Industry } \\
\text { Institute (CII). }\end{array}$ & $\begin{array}{l}\text { Questionnaires and } \\
\text { case studies }\end{array}$ & USA \\
\hline [14] & $\begin{array}{c}\text { Lean } \\
\text { Construction } \\
\text { Concept Model } \\
\text { (LCCM) }\end{array}$ & $\begin{array}{l}\text { Summarize the most } \\
\text { relevant Lean Construction } \\
\text { principles and concepts. }\end{array}$ & Literature study & Malaysia \\
\hline
\end{tabular}

Based on the analysis of the above-mentioned models we identify nine main principles that represent the basis of Lean Construction approach and which are: Customer focus, Supply, Continuous improvement, Waste elimination, People involvement, planning and Scheduling, Quality, Standardization, Transparency, as shown in Table 3. 
Table 3. The main principles used in LC models

\begin{tabular}{lccccc} 
& LCMM & LCCM & LCR & LCF & LCM \\
\hline Customer focus & $\checkmark$ & $\checkmark$ & $\checkmark$ & $\checkmark$ & $\checkmark$ \\
Supply & & $\checkmark$ & $\checkmark$ & $\checkmark$ & \\
Continuous improvement & $\checkmark$ & $\checkmark$ & $\checkmark$ & & $\checkmark$ \\
Waste elimination & $\checkmark$ & $\checkmark$ & $\checkmark$ & & $\checkmark$ \\
People involvement & $\checkmark$ & & & $\checkmark$ & $\checkmark$ \\
Planning and Scheduling & & & $\checkmark$ & $\checkmark$ & \\
Quality & & $\checkmark$ & $\checkmark$ & & \\
Standardization & & & $\checkmark$ & & $\checkmark$ \\
Transparency & $\checkmark$ & $\checkmark$ & & & \\
\hline
\end{tabular}

In addition, these principles can be divided into three primary pillars:

- Systems management: it focuses on the management of systems in interaction with customers, suppliers, and contractors (Customer focus, Supply, Planning and Scheduling);

- Technology management: It concerns the operational techniques aimed at optimizing the performance of the company (Transparency, Standardization, and Quality);

- Culture and behaviour: This pillar encompasses all Lean Construction practices that allow the dissemination of a culture of continuous improvement during all cycle of production while ensuring an optimal use of employee skills (people involvement, continuous improvement).

These three pillars are based on eliminating waste which is the core of the lean construction philosophy, as illustrated in Figure 5.

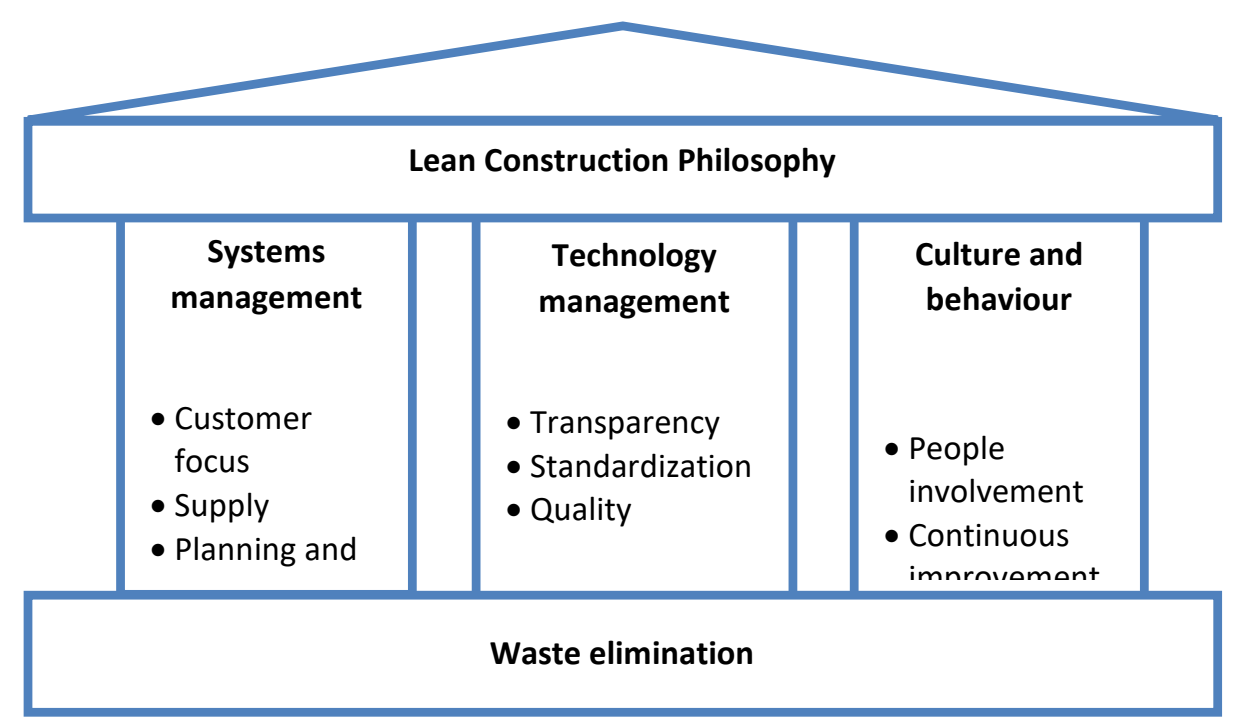

Figure 5. Main pillars of Lean Construction philosophy 


\section{PRACTICAL RELATIONSHIPS BETWEEN LEAN CONSTRUCTION PRINCIPLES AND SOURCES OF WASTE}

The sources of wastes are defined as activities/tasks that consume the resources of the company but don't generate the value for internal or external customers [15]. The seven forms of waste identified by Toyota, which are known as the seven Muda, are as follows: Transportation, Motion, Inventory, Waiting, Overproduction, Defects, defects and Overprocessing [5]. Several researchers have added "Unused employee creativity" as the eighth source of waste [16-18]. Recently, professionals and researchers interested in improving working conditions within the construction site have begun to emphasize the importance of reducing the accident rate and therefore they consider work accidents as the ninth source of waste [19-22]. In this section, we focus on identifying the practical relationship between LC principles that we've determined previously, and the nine types of wastes existing in the construction sector.

\section{Transportation}

Transportation activities concern the movement of materials between the different workstations as well as the established travel using the crane. These actions don't add value to the final product; instead, it caused an increase in the time of the production cycle, an inefficient use of working space and labour. Table 4 shows practical contributions of LC principles in reducing transport actions.

Table 4. Practical contributions of LC principles in reducing transport actions

\begin{tabular}{|c|c|c|}
\hline Principles & Practical contributions & Authors \\
\hline Supply & $\begin{array}{l}\text { The success of construction projects depends largely on } \\
\text { the ability of the project team to organize its logistics } \\
\text { flows (delivery/handling of materials and equipment in } \\
\text { the construction site) on the basis of the just-in-time } \\
\text { philosophy. }\end{array}$ & {$[23]$} \\
\hline $\begin{array}{c}\text { Waste } \\
\text { elimination }\end{array}$ & $\begin{array}{l}\text { LC practices/techniques such as (VSM, Cycle time } \\
\text { reduction, etc.) allow identifying logistic flow } \\
\text { weaknesses so that helps locate points requiring } \\
\text { improvement in order to reduce waste due to transport } \\
\text { actions. }\end{array}$ & {$[24]$} \\
\hline Standardization & $\begin{array}{l}\text { The standardization of transport methods makes logistics } \\
\text { flow more reliable and reduces hazardous transport } \\
\text { actions that generate waiting times. }\end{array}$ & {$[25]$} \\
\hline Transparency & $\begin{array}{l}\text { A transparent and well-organized workspace identifies } \\
\text { the areas of handling path to avoid blocking the flow. }\end{array}$ & [6] \\
\hline
\end{tabular}




\section{Defects (Non-Quality)}

Quality defects are considered a double source of waste generation, either in terms of the resources (labour, materials, equipment) to be implemented or on the level of turnover not generated during the entire repair period. Besides, defects have a negative effect on the synchronization of the planned tasks, the organization within the construction site and on the motivation of staff to repeat what has already been done in addition to the penalties [5]. Table 5 shows practical contributions of LC principles in reducing quality defects.

Table 5. Practical contributions of LC principles in reducing quality defects

\begin{tabular}{|c|c|c|}
\hline Principles & Practical contributions & Authors \\
\hline $\begin{array}{l}\text { Customer } \\
\text { Focus }\end{array}$ & $\begin{array}{l}\text { The ability to adapt to the changes proposed by the } \\
\text { customer allows building with the minimum of defects, } \\
\text { especially in the design phase. }\end{array}$ & {$[26]$} \\
\hline $\begin{array}{l}\text { Continuous } \\
\text { improvement }\end{array}$ & $\begin{array}{l}\text { The continuous improvement of constructive methods } \\
\text { and materials used allows companies to avoid the } \\
\text { recurrence of the defects resulting from obsolete } \\
\text { working methods. }\end{array}$ & {$[5]$} \\
\hline $\begin{array}{l}\text { Waste } \\
\text { elimination }\end{array}$ & $\begin{array}{l}\text { The staff awareness of the criticality of quality defects } \\
\text { on the profitability of the company promotes a mutual } \\
\text { responsibility to avoid the occurrence of such failures. }\end{array}$ & [27] \\
\hline $\begin{array}{c}\text { People } \\
\text { involvement }\end{array}$ & $\begin{array}{l}\text { Employee involvement in the problem-solving phase } \\
\text { can generate creative solutions that reduce the } \\
\text { frequency of occurrence of defects. }\end{array}$ & {$[6]$} \\
\hline $\begin{array}{l}\text { Planning \& } \\
\text { Scheduling }\end{array}$ & $\begin{array}{l}\text { LPS allows accomplishing the planning of tasks } \\
\text { according to the moral and physical capacity of the } \\
\text { labors which minimizes the defects that are generated } \\
\text { in the case of complex and too hard works. }\end{array}$ & {$[28]$} \\
\hline Quality & $\begin{array}{l}\text { The concept of quality is based on control sheets for } \\
\text { safety monitoring, Poka Yoke devices to avoid } \\
\text { intentional errors, and various problem-solving } \\
\text { techniques such as (Brainstorming System, Ishikawa, } \\
\text { Pareto, The five why ...) }\end{array}$ & [29] \\
\hline Standardization & $\begin{array}{l}\text { Standardized construction processes reduce the } \\
\text { occurrence of quality defects that are due to operator } \\
\text { hazardous actions as well as standardized repair } \\
\text { operations decrease the time spent during maintenance } \\
\text { work. }\end{array}$ & {$[30]$} \\
\hline
\end{tabular}




\section{Waiting}

Waiting is the direct results of a bad synchronization of the planned tasks, the absence of (materials, manpower, validation, plan, information) that are necessary to perform the required work or even the failure of equipment [6]. In the traditional system of construction project management, most of the time spent on construction sites is wasted in the form of waiting times. According to the study conducted by Dupin [5] the waiting time in construction projects goes to $29 \%$; it represents the largest share of time spent on the construction site. Table 6 shows practical contributions of LC principles in reducing waiting times.

Table 6. Practical contributions of LC principles in reducing waiting times

\begin{tabular}{cllc}
\hline Principles & \multicolumn{1}{c}{ Practical contributions } & Authors \\
\hline $\begin{array}{c}\text { Customer } \\
\text { Focus }\end{array}$ & $\begin{array}{l}\text { An organization with flexible production resources is } \\
\text { more likely to satisfy the changes proposed by the } \\
\text { customer all through the cycle of construction as best as } \\
\text { possible and with the minimum of waiting times. }\end{array}$ & \\
Supply & $\begin{array}{l}\text { The system just in time-based on the use of Kanban } \\
\text { cards and the Organization of work in a pull-flow supply }\end{array}$ & [5] \\
system flow minimizes significantly waiting times due \\
to the lack of materials by late orders, out of stock...
\end{tabular}




\section{Inventory}

The amount of storage on-site is an indicator of the level of waste, especially with a pushflow supply system. In fact, materials and materials stored and which will not be used in the short term, are the source of several negative effects for the company such as storage costs, scarcity of free space. As well as the degradation of materials stored under the effects of bad weather. Table 7 shows practical contributions of LC principles in reducing the inventory.

Table 7. Practical contributions of LC principles in reducing inventory

\begin{tabular}{|c|c|c|}
\hline Principles & Practical contributions & Authors \\
\hline Supply & $\begin{array}{l}\text { A large amount of on-site storage is the result of a push- } \\
\text { flow supply system. Contrary to this vision, the } \\
\text { philosophy of the LC is based on a system of pull-flow } \\
\text { supply system which allows ensuring only the quantity } \\
\text { really demanded in the stocks. Several techniques are } \\
\text { deployed to achieve this objective such as kanban cards, } \\
\text { supply chain management (SCM), preparation J-1. }\end{array}$ & {$[5]$} \\
\hline $\begin{array}{c}\text { Waste } \\
\text { elimination }\end{array}$ & $\begin{array}{l}\text { Value Stream Mapping (VSM) helps to identify critical } \\
\text { storage areas that contain materials or construction tools } \\
\text { that will not be used in the short-term construction } \\
\text { process. }\end{array}$ & {$[34]$} \\
\hline $\begin{array}{l}\text { Planning \& } \\
\text { Scheduling }\end{array}$ & $\begin{array}{l}\text { LPS made the correlation between planned work and } \\
\text { quantity of (materials/equipment) available on stock in } \\
\text { such a way not to have either an overstocking or a lack } \\
\text { of materials in stock }\end{array}$ & {$[35]$} \\
\hline Standardization & $\begin{array}{l}\text { Several projects based on the supply of prefabricated and } \\
\text { standardized elements have shown that this technique } \\
\text { helps to keep a minimum level of storage of raw } \\
\text { materials. }\end{array}$ & {$[36]$} \\
\hline Transparency & $\begin{array}{l}\text { The } 5 \mathrm{~S} \text { process and visual management make it easier to } \\
\text { manage the storage area and reduce the space occupied } \\
\text { by the stored materials. }\end{array}$ & {$[10]$} \\
\hline
\end{tabular}

\section{Over-processing}

Over-processing or too complex process, this type of waste concerns tasks and unnecessary extra work. This also includes tools that are more accurate, complex or costly than is necessary. Additional unnecessary work is considered as a waste that increases the cost of production and does not add value to the final product of construction [27]. Table 8 shows practical contributions of LC principles in reducing over processing. 
Table 8. Practical contributions of LC principles in reducing over processing

\begin{tabular}{clc}
\hline Principles & \multicolumn{1}{c}{ Practical contributions } & Authors \\
\hline $\begin{array}{c}\text { Continuous } \\
\text { improvement }\end{array}$ & $\begin{array}{l}\text { Continuous improvement allows thinking of more } \\
\text { optimal, simple and efficient work methods and } \\
\text { instructions. }\end{array}$ & {$[10]$} \\
$\begin{array}{c}\text { Waste } \\
\text { elimination }\end{array}$ & $\begin{array}{l}\text { Complex processes are critical to the quality of the } \\
\text { final product, the construction time, the cost invested } \\
\text { in the project. The awareness of personnel of the } \\
\text { criticality of this problem allows proposing simpler } \\
\text { and less expensive solutions. }\end{array}$ & {$[5]$} \\
& $\begin{array}{l}\text { The choice of methods work by the last planner } \\
\text { minimizes the instructions or specifications not clear } \\
\text { and not standardized. }\end{array}$ & {$[33]$} \\
Scheduling & & \\
Standardization & $\begin{array}{l}\text { Clear and standardized instructions or specifications } \\
\text { contribute significantly in reducing over processing. }\end{array}$ & {$[37]$} \\
\hline
\end{tabular}

\section{Overproduction}

Overproduction is to produce more than what is required by the customer or even build structures that will not be used and will be intended to be destroyed in the short term. The following table shows the practical contributions of the LC concepts in reducing overproduction. Table 9 shows practical contributions of LC principles in reducing overproduction.

Table 9. Practical contributions of LC principles in reducing overproduction

\begin{tabular}{clcc}
\hline Principles & \multicolumn{1}{c}{ Practical contributions } & Authors \\
\hline $\begin{array}{c}\text { Customer } \\
\text { Focus }\end{array}$ & $\begin{array}{l}\text { Integrating the customer into the value-added process } \\
\text { reduces unnecessary activities, so the production chain } \\
\text { focuses only on what is requested by the customer. }\end{array}$ & {$[38]$} \\
Supply & $\begin{array}{l}\text { The use of LC practices (Just-in-time/SCM/Pull } \\
\text { system/Customer involvement) is designed to determine in } \\
\text { detail the necessary resources for the construction process } \\
\text { (labor, equipment, materials, space) just at the time of need }\end{array}$ & \\
& $\begin{array}{l}\text { The culture of waste elimination helps the company to } \\
\text { identify non-value added processes as well as to determine } \\
\text { the roots of the overproduction causes. }\end{array}$ & \\
\hline elimination & & \\
\hline
\end{tabular}




\section{Motion}

This waste concern moves of operators, materials, and hardware that add no value to the cycle of production. On the contrary, they increase the difficulty of work for labor and increase the use of space. According to Dupin [5], a worker in the construction building walks between seven and nine kilometers. These displacements are due to several factors such as the research of equipment, raw materials, a plan or information, moving from one work area to another and so on. Table 10 shows practical contributions of LC principles in reducing motion.

Table 10. Practical contributions of LC principles in reducing motion

\begin{tabular}{clcc}
\hline Principles & \multicolumn{1}{c}{ Practical contributions } & Authors \\
\hline Supply & $\begin{array}{l}\text { An efficient logistics flow management system ensures the } \\
\text { availability of all the necessary elements for construction } \\
\text { processes (materials, tools, etc.) which minimizes }\end{array}$ & \\
& $\begin{array}{l}\text { unnecessary movements between the stock and } \\
\text { workstations. }\end{array}$ & \\
Waste & $\begin{array}{l}\text { Cycle time minimizing imperatively requires reducing the } \\
\text { time spent on unnecessary travel. }\end{array}$ & \\
& & \\
Transparency & $\begin{array}{l}\text { Visual management techniques make it easy to identify the } \\
\text { locations of the different elements (raw materials, Tools, } \\
\text { etc.) using signalling techniques. In addition, the 5S } \\
\text { process reduces unnecessary travel by keeping everything }\end{array}$ & \\
& in its proper place. & \\
\hline
\end{tabular}

\section{Unused employee creativity}

It is the eighth source of wasting. This type of waste characterizes traditional systems of production [40]. The orders are given by the section engineers and little place remains for the initiative and creativity, neither individual nor collective. According to several previous study [6,41-43], human potential can be considered as an important source of creative solutions to solve the root causes of problems within the construction company. Table 11 shows practical contributions of LC principles in reducing wastes generated in the case of unused employee creativity. 
Table 11. Practical contributions of LC principles in reducing unused employee creativity

\begin{tabular}{|c|c|c|}
\hline Principles & Practical contributions & Authors \\
\hline $\begin{array}{l}\text { Continuous } \\
\text { improvement }\end{array}$ & $\begin{array}{l}\text { Continuous Improvement culture promotes the } \\
\text { participation of all the actors of the project and } \\
\text { especially the labor. Indeed, the PDCA (Plan, Do, } \\
\text { Check, Act) approach cannot achieve its objectives } \\
\text { without human creativity. }\end{array}$ & [44] \\
\hline $\begin{array}{c}\text { Waste } \\
\text { elimination }\end{array}$ & $\begin{array}{l}\text { The consciousness of the criticality of non-added value } \\
\text { tasks motivates the integration of labour in the process } \\
\text { of identifying and eliminating wastes. }\end{array}$ & [45] \\
\hline $\begin{array}{c}\text { People } \\
\text { involvement }\end{array}$ & $\begin{array}{l}\text { People involvement is essentially intended to } \\
\text { incorporate the employees through training, meetings, } \\
\text { and so on which motivate them to participate in } \\
\text { improving the project performance. }\end{array}$ & [46] \\
\hline Quality & $\begin{array}{l}\text { Several techniques such as Brainstorming System, } \\
\text { Ishikawa, and the five why are based on the potential of } \\
\text { employees to generate maximum creative solutions. }\end{array}$ & [47] \\
\hline $\begin{array}{l}\text { Planning \& } \\
\text { Scheduling }\end{array}$ & $\begin{array}{l}\text { Last Planner System is a participatory planning tool that } \\
\text { considers the staff as the most reliable source of a } \\
\text { realistic plan especially as they are the closest to the } \\
\text { actual constraints and working conditions in the } \\
\text { construction site. }\end{array}$ & {$[48]$} \\
\hline
\end{tabular}

\section{Accidents}

Injuries and fatality are considered as the ninth source of waste [20-22,49-51]. The death or injury of labours leads to a loss in the process reliability and creates additional costs such as insurance costs, high medical treatment costs, and a rehabilitation program. In addition to that, poor conditions of work generate indirect losses such as a decrease in productivity as well as the reduction in staff motivation [21]. Table 12 shows practical contributions of LC principles in reducing accidents on construction sites.

Table 12. Practical contributions of LC principles in reducing work accidents

\begin{tabular}{clc}
\hline Principles & \multicolumn{1}{c}{ Practical contributions } & Authors \\
\hline $\begin{array}{c}\text { Continuous } \\
\text { improvement }\end{array}$ & $\begin{array}{l}\text { Improving on-going performance indicators is a major pillar } \\
\text { of continuous improvement. The accident rate is one of the } \\
\text { most important indicators within the construction site, and } \\
\text { that needs the implementation of precautions to reduce it to }\end{array}$ & \\
& $\begin{array}{l}\text { the minimum possible. } \\
\text { Waste }\end{array}$ & $\begin{array}{l}\text { The consciousness of the criticality of accidents on } \\
\text { construction sites makes the workforce more cautious in } \\
\text { terms of compliance with the safety instructions. }\end{array}$ \\
\hline
\end{tabular}




\begin{tabular}{|c|c|c|}
\hline $\begin{array}{c}\text { People } \\
\text { involvement }\end{array}$ & $\begin{array}{l}\text { The incorporation of the staff in the safety management } \\
\text { allows reducing the rate of accidents through training, daily } \\
\text { meetings... }\end{array}$ & [51] \\
\hline $\begin{array}{l}\text { Planning- } \\
\text { Scheduling }\end{array}$ & $\begin{array}{l}\text { The empowerment of employees to commit themselves to } \\
\text { the tasks they could perform over a period of time } \\
\text { contributes tangibly to the reduction of accidents. Moreover, } \\
\text { the Last planner system involves the continuous monitoring } \\
\text { of the process flow in such a way to maintain the correlation } \\
\text { between the skills of workers with tasks scheduled. } \\
\text { Moreover, the implication of labors in the selection of the } \\
\text { construction methods, which correspond to their capacity, } \\
\text { could increase the motivation of the staff and, consequently, } \\
\text { the accidents related to the mental issues and excessive stress } \\
\text { could be minimized. }\end{array}$ & [49] \\
\hline Quality & $\begin{array}{l}\text { Qualitative tools such as Brainstorming System, Ishikawa, } \\
\text { and the five why help to identify the root causes of } \\
\text { workplace accidents. In addition, Poka-yoke devices are } \\
\text { considered an innovative manner to avoid unintentional } \\
\text { errors by launching an alarm in case of danger or even stop } \\
\text { the process in progress. Furthermore, these gadgets prevent } \\
\text { employees from crossing or approaching from dangerous } \\
\text { places (excessive heat, noise, dust, falling objects, concrete } \\
\text { elements waiting for drying ...) through an audible or } \\
\text { luminous alarm. }\end{array}$ & [25] \\
\hline Standardization & $\begin{array}{l}\text { Let the operators perform dangerous tasks (Cutting, drilling, } \\
\text { and casting of concrete) with their own way which increases } \\
\text { the risk of injuries and deaths at construction sites. Indeed, } \\
\text { the use of standardized processes minimized the level of } \\
\text { hazardous action which helps companies reduce the } \\
\text { occupational accidents. }\end{array}$ & {$[52]$} \\
\hline Transparency & $\begin{array}{l}\text { A poorly organized workplace is classified among the main } \\
\text { causes of accidents on the construction site. The } 5 \mathrm{~S} \\
\text { approach and visual management lead to a well-organized } \\
\text { construction site which promotes the safety and the } \\
\text { productivity of the workforce. }\end{array}$ & [40] \\
\hline
\end{tabular}

\section{DEVELOPMENT OF AN INPUT-OUTPUT MODEL OF LEAN CONSTRUCTION}

Generally, the construction system is an input-output model. This system contains as input the components needed to start the transformation stage in order to reach the construction product at the end respecting the deadline, the cost of the project and minimizing all types of waste. As illustrated in Figure 6, we have developed an inputoutput model adapted to the construction context. 


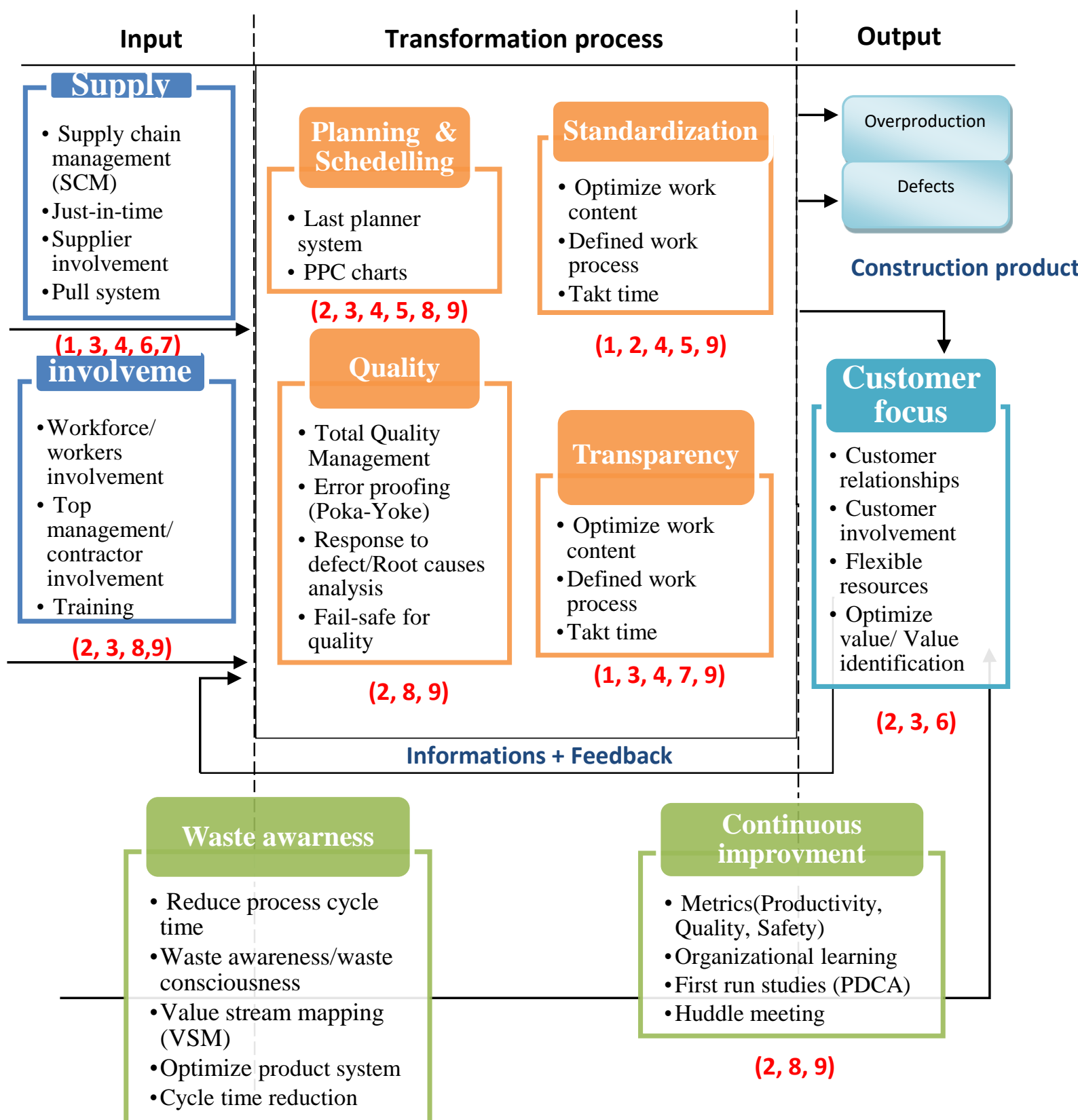

$(1,2,3,4,5,6,7,8$,

1: Transportation 2: Defects (Non-Quality) 3: Waiting 4: Inventory 5: Ove-processing 6: Overproduction 7: Motion 8: Unused employee creativity 9: Accidents.

Figure 6. An Input-output model illustrating the practical relationships between LC principles and sources of waste

This model is based on the main principles which we have determined by analysing the most reliable models dealing with the implementation of the Lean Construction philosophy. In addition, Figure 6 shows LC techniques and tools that could be used by construction companies to reduce each type of waste. People Involvement and Supply constitute the basis of the input phase because they ensure all the sources necessary to begin the transformation phase (labour, materials, equipment...). 
The transformation process contains four main principles: Quality, Planning \& Scheduling, Standardization, and Transparency. These principles are intended to respect the triptych (quality, cost, time) while ensuring the best conditions of work for labours.

Customer focus plays a major role in the output phase by transferring information and feedback to the input phase. This operation remains valid throughout all the cycle of the project (design, Construction, delivery) which make it possible to reduce the generation of construction infrastructure not requested by the customer (overproduction), or the appearance of defects in the construction product at the delivery phase (defects).

Waste elimination and continuous improvement are integrated throughout the construction cycle, starting from the beginning to the end of the project. They are important for the performance of construction projects during the three stages of the project (Input phase, Transformation phase, Output phase). In addition, these two concepts make it possible to ensure the permanent improvement of (quality, cost, time) and to replace the traditional management techniques by a rigorous and systematic approach of waste reduction. Figure 6 also shows the practical relationship between the principles of Lean Construction and all forms of waste (Transportation, Motion, Inventory, Waiting, Overproduction, Defects, defects, over-processing, unused employee creativity, and accidents).

\section{CONCLUSION}

This work was intended to provide an input-output model that shows the principles of Lean Construction. Initially, the most relevant principles have been identified, based on models that have been applied in several countries (USA, UK, Malaysia, Germany and Brazil). Nine principles have been identified (Customer focus, Supply, Continuous improvement, Waste elimination, People involvement, planning and Scheduling, Quality, Standardization, and Transparency).

In addition, the practical relationships between those principles and the different sources of waste (Transportation, Motion, Inventory, Waiting, Overproduction, Defects, Over Processing, Unused Employee Creativity, and Work Accidents) have been investigated based on a rigorous review of the best-known bibliographic references published in several databases as DOAJ, ISI Web of Science, and Scopus. This research leads to a better understanding of Lean Construction principles.

Moreover, this work can help construction companies choose the most appropriate techniques for each type of waste. In perspective, further researches, especially empirical studies, are needed to test, validate, and improve the proposed theoretical input-output model.

\section{REFERENCES}

[1] Koskela L. Management of production in construction: a theoretical view. Proc IGLC-7. 1999; 241-52.

[2] Tezel, A, Nielsen, Y. Lean construction conformance among construction contractors in Turkey. Journal of management in engineering. 2012; 29(3):236250.

[3] Bajjou MS, Chafi A. Barriers of Lean Construction Implementation in the Moroccan Construction Industry. In AIP Conference Proceedings. 2018; 1952 (1): p. 020056. AIP Publishing. 
[4] Nordin, N, Adebambo, HO. Descriptive analysis of sustainable manufacturing indicators in Malaysian manufacturing firms. Journal of Mechanical Engineering and Sciences. 2016; 201610(2):2126-2133.

[5] Dupin P. Le lean appliqué à la construction, comment optimiser la gestion de projet et réduire coûts et délais dans le bâtiment.: Groupe Eyrolles, Paris, 2014.

[6] Harris F, McCaffer R. Modern Construction Management. John Wiley \& Sons. 2013.

[7] Aziz RF, Hafez SM. Applying lean thinking in construction and performance improvement. Alexandria Engineering Journal. 2013; 52(4):679-95.

[8] Bajjou MS, Chafi A, En-nadi A. A Comparative Study between Lean Construction and the Traditional Production System. International Journal of Engineering Research in Africa; 2017; 29:118-32.

[9] Bajjou MS, Chafi A. Towards Implementing Lean Construction in the Moroccan Construction Industry: Survey Study. In : Optimization and Applications (ICOA), 2018 4th International Conference. 2018; p. 1-5. IEEE.

[10] Hofacker A., Oliveira BF, Gehbauer F, Freitas MDCD, Mendes Júnior R, Santos A, Kirsch, J. Rapid lean construction-quality rating model (LCR). In 16th International Group for Lean Construction Conference (IGLC16). 2008;(July):111.

[11] Nesensohn C, Bryde D, Pasquire C. A measurement model for lean construction maturity. Lean Construction Journal. 2016; pp 01-09.

[12] Johansen E, Walter L. Lean Construction: Prospects for the German construction industry. Lean Construction Journal. 2007;3(April):19-32.

[13] Diekmann J, Balonick J, Krewedl M, Troendle L. Measuring lean conformance. In Proc. 11th Ann. Conf. Intl. Group for Lean Construction. 2003;(Cii):2-8.

[14] Jeni, A, Luthfi M, Akasah Z. A. Implementation of lean construction concept among contractors in Malaysia.. International Conference on Engineering and Built Environment (ICEBE). 2012;0112671200(2):1-6.

[15] Womack JP, Jones DT, Roos D. Machine that changed the world. Simon and Schuster. 1990.

[16] Ling FYY, Ke Y, Kumaraswamy MM, Wang S. Key Relational Contracting Practices Affecting Performance of Public Construction Projects in China. Journal of Construction Engineering and Management, 140(1), 04013034.

[17] Yang JL, Peng Y, Chen YS. On Improving the Competitiveness of Real Estate Enterprises Based on the Concept of Lean Construction. In Advanced Materials Research(Vol. 689, pp. 444-447). Trans Tech Publications. 2013;689:444-7.

[18] Wahab ANA, Mukhtar M, Sulaiman R. A Conceptual Model of Lean Manufacturing Dimensions. Procedia Technology, 11, 1292-1298.

[19] Zhu K, Lv J. Research on the improvement effect of lean thinking to construction safety management. In 26th Chinese Control and Decision Conference (2014 CCDC). 2014;1428-33. IEEE.

[20] Antillón EI, Alarcón LF, Hallowell MR, Molenaar KR. A research synthesis on the interface between lean construction and safety management. 19th Annual Conference of the International Group for Lean Construction. 2011;615-25.

[21] Ghosh S, Young-Corbett D. Intersection between lean construction and safety research: a review of the literature. In Proceedings of the 2009 Industrial Engineering Research Conference. 2009; 30. 
[22] Enshassi A, Zaiter MA. Implementation of lean tools on safety in construction projects in palestine. 22nd Annu Conf Int Gr Lean Constr Underst Improv Proj Based Prod IGLC. 2014;1205-18.

[23] Thiruchelvam S, Tookey JE, Samarasinghe DAS, Hock QW, Mustapha KN. Supplier selection criteria in a power utility in malaysia: engineers'perceptions. Journal of Mechanical Engineering and Sciences. 2012; 2(June):148-161.

[24] Salem O, Solomon J, Genaidy A, Minkarah I. Lean Construction: From Theory to Implementation. Journal of management in engineering. 2006;22(4):168-75.

[25] Ab Rashid MFF, Nik Mohamed NMZ, Mohd Rose AN, Kor KY. Simulation Study Of A Vehicle Production Line For Productivity Improvement. Journal of Mechanical Engineering and Sciences. 2015;8(1):1283-1292.

[26] Janipha NAI, Ahmad N, Ismail F. Clients' Involvement in Purchasing Process for Quality Construction Environment. Procedia-Social and Behavioral Sciences. 2015;168:30-40.

[27] Bajjou MS, Chafi A, Ennadi A, El Hammoumi M. The Practical Relationships between Lean Construction Tools and Sustainable Development: A literature review. Journal of Engineering Science \& Technology Review. 2017;10(4):170177.

[28] Kongguo Z. Research on the emergence mechanism of Last Planner System of lean construction. In Control and Decision Conference (2014 CCDC), The 26th Chinese. 2014, May; 3643-3646. IEEE.

[29] Love PE, Teo P, Morrison J, Grove M. Quality and safety in construction: creating a no-harm environment. Journal of Construction Engineering and Management. 2016; 142(8):05016006.

[30] Hook M, Stehn L. Lean Principles in Industrialized Housing Production: The Need for a Cultural Change Lean Culture. Lean Construction Journal. 2008;2033.

[31] Thomas HR, Horman MJ, Minchin RE, Chen D. Improving Labor Flow Reliability for Better Productivity as Lean Construction Principle. Journal of construction engineering and management. 2003; 129(3):251-261.

[32] Erikshammar J, Lu W, Stehn L, Olofsson T. Discrete Event Simulation Enhanced Value Stream Mapping: An Industrialized Construction Case Study. Lean Construction Journal. 2013;10:47-65.

[33] Chouiraf, F, Chafi, A. Lean manufacturing for handicraft production: A new production system to enhance productivity and competitiveness of craft enterprise. In Optimization and Applications (ICOA), 2018 4th International Conference. 2018, April: 1-6. IEEE.

[34] Rahani AR., Al-Ashraf M. Production flow analysis through value stream mapping: a lean manufacturing process case study. Procedia Engineering. 2012; 41: 1727-1734.

[35] Lindhard, S., \& Wandahl, S. (2015). Exploration of correct LPS practices in scheduling of large, complex, and constrained construction projects. International Journal of Project Organisation and Management, 7(1), 56-71.

[36] Jaillon L, Poon CS, Chiang YH. Quantifying the waste reduction potential of using prefabrication in building construction in Hong Kong. Waste management. 2009; 29(1): 309-320.

[37] El-Kourd, R. A study of lean construction practices in Gaza Strip. Phd thesis. Faculty of Civil Engineering Department. 2009. 
[38] Mastura M, Sapuan S, Mansor M. A framework for prioritizing customer requirements in product design: Incorporation of FAHP with AHP. Journal of Mechanical Engineering and Sciences. 2015; 9(Deecember):1655-1670.

[39] Hosseini, S. A., Nikakhtar, A., \& Ghoddousi, P. (2012). Flow production of construction processes through implementing lean construction principles and simulation. International Journal of Engineering and Technology, 4(4), 475.

[40] Bajjou MS, Chafi A, En-Nadi A. The Potential Effectiveness of Lean Construction Tools in Promoting Safety on Construction Sites. International Journal of Engineering Research in Africa. 2017; 33: 179-193.

[41] Bortolotti T, Boscari S, Danese P. Successful lean implementation: Organizational culture and soft lean practices. International Journal of Production Economics. 2015; 160:182-201.

[42] Alarcón L. Lean construction. CRC Press. 2014.

[43] Marhani MA, Jaapar A, Bari NAA. Lean Construction: Towards enhancing sustainable construction in Malaysia. Procedia-social and behavioral sciences. 2012; 68:87-98.

[44] Savolainen J, Kähkönen K, Niemi O, Poutanen J, Varis E. Stirring the construction project management with co-creation and continuous improvement. Procedia Economics and Finance. 2015. 21:64-71.

[45] Issa UH. Implementation of lean construction techniques for minimizing the risks effect on project construction time. Alexandria Engineering Journal. 2013; 52(4):697-704.

[46] Nesensohn C, Demir ST, Bryde, DJ. Developing the Truth North route map as a navigational compass in a construction project management organization. Lean Construction Journal. 2013; 1-18.

[47] Ferng J, Price AD. An exploration of the synergies between Six Sigma, total quality management, lean construction and sustainable construction. International Journal of Six Sigma and Competitive Advantage. 2015; 1(2):167-187.

[48] Ochoa JJ. Reducing plan variations in delivering sustainable building projects. Journal of cleaner production. 2014; 85:276-288.

[49] Bashir AM, Suresh S, Proverbs D, Gameson R. A critical, theoretical, review of the impacts of lean construction tools in reducing accidents on construction sites. In Proceedings of 27th Annual ARCOM Conference, Bristol, UK, Association of Researchers in Construction Management; 2011, September; 5-7.

[50] Nahmens I, Ikuma LH. An Empirical Examination of the Relationship between Lean Construction and Safety in the Industrialized Housing Industry. Lean Construction Journal. 2009; 1-12.

[51] $\mathrm{Ng} \mathrm{K}$, Laurlund A, Howell G, Lancos G. Lean safety: using leading indicators of safety Incidents to improve construction safety. In Proceedings for the 20th Annual Conference of the International Group for Lean Construction: are We Near a Tipping Point. 2012; p. 173.

[52] Sacks R, Treckmann M, Rozenfeld O. Visualization of work flow to support lean construction. Journal of Construction Engineering and Management. 2009; 135(12):1307-1315. 